\section{BALIK TOPENG MASKULINITAS IKLAN ROKOK: KRITIK TERHADAP IKLAN ROKOK A MILD MEDIA OUTDOOR VERSI BERANI TAKUT}

Nadia Sigi Prameswari

Jurusan Pengkajian Seni, Minat Utama Desain Komunikasi Visual Program Studi Pascasarjana, Institut Seni Indonesia Yogyakarta

Email: mimimomot@gmail.com

\section{Abstrak}

Tujuan kajian ini adalah memberikan pengertian, apresiasi, dan evaluasi mengenai fenomena di balik iklan rokok A Mild media outdoor versi Berani Takut. Metode yang digunakan dalam kajian ini adalah studi pustaka dan observasi. Iklan rokok A Mild versi Berani Takut menjadikan maskulinitas sebagai bentuk komodifikasi dalam penyampaian pesan iklan. Hubungan antara komodifikasi maskulinitas dan realitas adalah bertolak belakang. Imaji maskulinitas yang dibentuk dari iklan hanyalah fragmen ideologi yang terbentuk dari konotator pada tahapan mitos. Keterkaitan antara hasil analisis semiotika dengan ketiga contoh iklan tidak menampilkan realitas produk yang sesungguhnya (mirror of reality), melainkan realitas yang tidak sesungguhnya dari sebuah produk (distorted of mirror reality).

Kata Kunci: iklan rokok A Mild, media outdoor, komodifikasi, maskulinitas, realitas.

\section{BALIK TOPENG MASKULINITAS IKLAN ROKOK: KRITIK TERHADAP IKLAN ROKOK A MILD MEDIA OUTDOOR VERSI BERANI TAKUT}

\section{Abstract}

The research is aimed at giving the understanding, appreciation, and evaluation of a phenomenon behind Berani Takut version of A Mild ciggarette outdoor advertisement. The method used in this study is library research and observtion on this advertisement, in which masculinity as a form of commodification in delivering messages is used in advertisement. Masculinity commodification and reality are disparately connected. The imagination of masculinity shaped in an advertisement is only a kind of fragments of ideology which are formed based on the connotators of myths. The connection between the results of semiotic analysis and the three examples of advertisements does not mirror the reality of the products, but rather shows its distorted reality.

Keywords: A Mild cigarette advertisement, outdoor advertisement, commodification, masculinity, reality 


\section{PENDAHULUAN}

Perkembangan iklan dan periklanan (advertising) di dalam masyarakat konsumer dewasa ini telah memunculkan berbagai persoalan sosial dan kultural mengenai iklan, khususnya mengenai tanda (sign) yang digunakan, citra (image) yang ditampilkan, informasi yang disampaikan, makna yang diperoleh, serta bagaimana semuanya memengaruhi persepsi, pemahaman, dan tingkah laku masyarakat. Apakah sebuah iklan menampilkan realitas tentang sebuah produk yang ditawarkan, atau sebaliknya topeng realitas (Piliang, 2010:279).

Di antara berbagai iklan komersial yang beredar di berbagai media, iklan rokok seringkali menimbulkan kontroversi. Dewasa ini iklan rokok cenderung tidak mengangkat komoditas rokok sebagai komoditas utama yang diperdagangkan. Dengan kata lain, pesan iklan disampaikan sebagai upaya kapitalisme mengubah nilai fungsi (use value) atau guna menjadi sebuah nilai tukar (exchange value) untuk tujuan komersial, atau yang biasa disebut dengan komodifikasi (Mosco, 2010:129).

Hal itu tidak lepas dari pengaruh pemberlakuan PP Nomor 109 Tahun 2012 pasal 39 yang menyatakan bahwa setiap orang dilarang menyiarkan dan menggambarkan dalam bentuk gambar atau foto, menayangkan, menampilkan atau menampakkan orang sedang merokok, memperlihatkan batang rokok, asap rokok, bungkus rokok atau yang berhubungan dengan Produk Tembakau (www.depkes.go.id, online).

Ketatnya regulasi pembatasan iklan rokok tidak menjadikan surutnya pendapatan perusahaan rokok kapitalis di Indonesia. Berdasarkan data yang diperoleh dari Kementerian Perindustrian, valuasi PT Hanjaya Mandala Sampoerna Tbk (HMSP), pemimpin pasar rokok di Indonesia, menduduki urutan tertinggi pada kuartal I 2012 (agro.kemenperin.go.id, online). Tercatat bahwa A Mild, salah satu varian rokok yang diproduksi oleh HMSP mampu mempertahankan posisi sebagai merek rokok dengan pangsa pasar terbesar di Indonesia. Data tersebut diperoleh berdasarkan Nielsen Retail Audit Results Full Year 2011 (www.sampoerna.com, online). Oleh karena itu, tulisan ini menitikberatkan iklan rokok A Mild media outdoor versi Berani Takut dalam sudut pandang kritik yang erat kaitannya dengan persoalan sosial dan kultural. Tujuan dari kajian ini adalah memberikan pengertian, apresiasi, dan evaluasi mengenai fenomena dibalik iklan rokok A Mild media outdoor versi Berani Takut. Metode kajian ini adalah melalui studi pustaka dan observasi.

\section{LANDASAN TEORI}

a. Kritik Seni

Istilah critic dalam bahasa Inggris sudah ada sejak tahun 1588. Secara etimologi kata tersebut berasal dari bahasa Latin, criticus, bahasa Yunani, kritikos yang erat hubungannya dengan krinein yang berarti memisahkan, mengamati, menilai, dan menghakimi (Merriam Webster's Collegiate Dictionary). Lebih lanjut dalam Merriam Webster's Collegiate Dictionary disebutkan bahwa arti kritik adalah (1) one who expresses a reasoned opinion on any matter especially involving a judgment of its value, truth, righteousness, beauty, or technique; (2) one who engages often professionally in the analysis, evaluation, or appreciation of works of art or artistic performances; (3) one given to harsh or captious judgment.

Dalam rumusan Webster's tersebut disebutkan bahwa maksud kritik adalah orang yang menyampaikan pendapatnya dengan alasan tertentu terhadap berbagai hal, terutama mengenai nilai, kebenaran, kebajikan, kecantikan atau tekniknya. Berikutnya dinyatakan bahwa arti kritik adalah orang yang melibatkan diri secara profesi dalam menganalisis, mengevaluasi atau memberi penghargaan kepada karya seni atas pencapaian artistiknya. Terakhir dinyatakan bahwa maksud kritik adalah seseorang yang memberikan pelilaian dengan cerdik atau tajam.

Sementara itu, pengertian criticism adalah: (1) the act of criticizing usually unfavorably; a critical observation or remark; critique (2) the art of evaluating or analyzing works of art or literature; (3) the scientific investigation of literary documents in regard to such matters as origin, text, composition, or history. Menurut penjelasan tersebut, tindakan mengkritik dalam kehidupan sehari-hari umumnya tidak mendukung atau menguntungkan bagi yang dikritik; suatu pengamatan yang kritis atau teguran. Padanan kata critique dalam batasan di atas berarti kupasan atau tinjauan. Dalam seni, mengkritik berarti mengevaluasi atau meneliti karya seni atau literatur.

Mengkritik diartikan pula sebagai sebuah penyelidikan ilmiah dari naskah atau dokumen yang terkait dengan kesusasteraan dalam hubungan dengan berbagai hal, seperti keasliannya, teks, komposisi, atau sejarahnya. Feldman (1967:470-486) menyatakan bahwa terdapat empat unsur kritik seni. Keempat unsur tersebut adalah deskripsi, analisis formal, interpretasi, dan evaluasi. Masingmasing unsur kritik seni tersebut dapat dijelaskan sebagai berikut. 


\section{Deskripsi}

Deskripsi dalam kritik seni adalah uraian berupa penjelasan dasar tentang apa saja yang tampak secara visual, dan diharapkan dalam penjelasan tersebut dapat membangun bayangan atau image bagi pembaca mengenai karya seni yang disajikan. Deskripsi bukan dimaksudkan untuk menggantikan karya itu sendiri, tetapi diharapkan dapat memberi penjelasan mengenai gambaran visual mengenai citra yang ditampilkan secara jelas dan gamblang. Pada tahapan deskripsi, penilaian atau keputusan mengenai karya seni dapat ditangguhkan terlebih dahulu, karena kritik harus mendahulukan penjelasan-penjelasan dasar berupa suatu gambaran yang lengkap. Selain itu, uraian deskripsi juga tidak mengindahkan interpretasi atau tafsiran awal sebelum bukti-bukti, dan data-data, serta fakta konsep berkarya berhasil dikumpulkan.

Uraian deskripsi biasanya ditulis sesuai dengan keadaan karya sebagaimana apa adanya, dan juga berusaha menelusuri gagasan, tema, teknis, media, dan cara pengungkapannya. Uraian deskripsi meliputi uraian mengena hal-hal yang diwujudkan pada karya secara kasat mata mengenai garis, bidang, warna, tekstur dan lain-lain, tanpa mencoba memberikan interpretasi dan penilaian, sehingga uraian deskripsi menjelaskan secara umum apa-apa saja yang terlihat dalam pandangan mata, tanpa harus memancing perbedaan pendapat atau berusaha memperkecil perbedaan penafsiran.

\section{Analisis Formal}

Analisis formal merupakan tahapan berikutnya. Proses ini dapat dimulai dengan cara menganalisis obyek secara keseluruhan mengenai kualitas unsurunsur visual dan kemudian dianalisis bagian demi bagian, seperti menjelaskan tata cara pengorganisasian unsur-unsur elementer kesenirupaan, berupa kualitas garis, bidang, warna, dan tekstur. Selain itu juga menjelaskan bagaimana komposisi karya secara keseluruhan dengan masalah keseimbangan, irama, pusat perhatian, unsur kontras, dan kesatuan. Analisis formal dapat dimulai dari gagasan, proses pewujudan karya, beserta urutannya.

Pada saat persoalan komposisi mulai dibicarakan maka mulai diuraikan perkara tata cara pengukuran yang disesuaikan dengan rancangan dan kandungan maknanya. Salah satu pendekatan yang dapat digunakan dalam analisis formal adalah semiotika. Hal ini karena semiotika merupakan ilmu tanda yang dapa menata penyerapan manusia dalam melihat berbagai gagasan, abstraksi, pendirian, pertimbangan, hasrat, kepercayaan, serta pengalaman tertentu dalam bentuk yang dapat dihayati dan dimengerti secara bersama. Perbandinganperbandingan mulai dapat dilakukan sebagai suatu cara untuk mencapai intensitas perubahan pemikiran dalam sebuah proses pengubahan karya. Analisis forma tetap berangkat dari wujud nyata dalam karya dengan langkah kajian yang lebih bersifat menganalisis kualitas tanda, sehingga sampai pada proses ini pernyataan atau ungkapan seniman belum diperlukan sebagai sebuah data, kecuali jika diperlukan catatan-catatan yang berbeda dengan realitas karya yang disajikan. Tahapan ini telah menjelaskan karya secara obyektif mengenai kualitas tandatanda yang ada pada karya, dan dimulai telaah ke arah bagaimana menafsirkan ben-tuk.

\section{Interpretasi}

Intepretasi adalah menafsirkan hal-hal yang terdapat di balik sebuah karya, dan menafsirkan makna, pesan, atau nilai yang dikandungnya. Setiap penafsiran justru dapat mengungkap hal-hal yang berhubungan dengan pernyataan di balik struktur bentuk, misalnya unsur psikologis pencipta karya, latar belakang sosial budayanya, gagasan, abstraksi, pendirian, pertimbangan, hasrat, kepercayaan, serta pengalaman tertentu senimannya. Penafsiran merupakan salah satu cara untuk menjernihkan pesan, makna, dan nilai yang dikandung dalam sebuah karya, dengan cara mengungkapkan setiap detail proses intepretasi dengan bahasa yang tepat. Untuk menjelaskan secara tepat, maka seseorang yang melakukan penafsiran harus berbekal pengetahuan tentang proses pengubahan karya.

Sebuah karya seni membutuhkan penafsiran yang tepat jika dimaksudkan untuk membuat suatu penilaian yang kritis. Pada umumnya penguraian berdasarkan metode yang ilmiah tentang struktur bentuk karya, dan hubungan setiap elemen unsur rupa sangat bermanfaat untuk melandasi interpretasi. Bentuk penilaian pada karya seni rupa merupakan gabungan antara pribadi seniman dengan gagasan atau ide yang dijadikan konsep dalam berkarya, permasa-lahan yang akan dikemukakan seniman serta seberapa jauh masalah tersebut dapat diselesaikan, tema yang akan digarap dan bagaimana penggarapannya, materi yang dipilih untuk mewujudkan karya, teknik yang digunakan, serta pengalaman dan latar belakang seniman, kesemuanya saling terkait dan berhubungan untuk menunjang sebuah interpretasi yang tepat.

\section{Evaluasi/Penilaian}

Sebuah penilaian didasarkan atas deskripsi, analisis formal, dan intepretasi sebuah karya seni dengan data-data visual maupun penjelasanpenjelasan tambahan dari seniman. Tahap evaluasi atau penilaian ini pada dasarnya merupakan proses menetapkan derajat karya seni rupa bila dibandingkan dengan karya seni rupa lainnya yang sejenis. Tingkat penilaiannya ditetapkan berdasarkan nilai estetik secara relatif dan kontekstual. Dalam menilai sebuah karya seni rupa sedapat mungkin mengaitkan karya yang ditelaah dengan sebanyak mungkin karya seni rupa yang sejenis dengan maksud mencari ciri-ciri 
khususnya, kemudian menetapkan tujuan atau fungsi karya yang sedang ditelaah, menetapkan sampai seberapa jauh karya yang sedang ditelaah tersebut berbeda dari yang telah ada sebelumnya dan mencari karakteristiknya, dan terakhir menelaah karya yang dimaksud dari segi kebutuhan khusus dan sudut pandang tertentu yang melatarbelakanginya.

\section{b. Teori Semiotika Roland Barthes}

Pendekatan semiotik Roland Barthes secara khusus tertuju kepada sejenis tuturan (speech) yang disebutnya sebagai mitos. Menurut Barthes (1983:109-131), bahasa membutuhkan kondisi tertentu untuk dapat menjadi mitos, yaitu yang secara semiotik dicirikan oleh hadirnya sebuah tataran signifikasi yang disebut sebagai sistem semiologis tingkat kedua (the second order semiological syste).

Pada tataran bahasa atau sistem semiologis tingkat pertama (the first order semioligical system), penanda-penanda berhubungan dengan petanda-petanda sedemikian sehingga menghasilkan tanda. Selanjutnya tanda-tanda pada tataran pertama hanya akan menjadi penanda-penanda yang berhubungan dengan petanda-petanda pada tataran kedua. Pada tataran signifikasi lapis kedua inilah mitos (Barthes, 1983: 114-115). Aspek material mitos yakni penanda-penanda pada the second order semiological system itu, dapat disebut sebagai retorik atau konotator-konotator yang tersusun dari tanda-tanda pada sistem pertama; sementara petanda-petandanya sendiri dapat dinamakan sebagai fragmen ideologi (Barthes, 1981:91).

1. Di dalam tataran bahasa (langue), yaitu sistem semiologis lapis pertama, penanda-penanda berhubungan dengan petanda-petanda sedemikian sehingga menghasilkan tanda.

2. Di dalam tataran mitos, yakni sistem semiologis lapis kedua, tanda-tanda pada tataran pertama tadi menjadi penanda-penanda yang berhubungan lagi dengan petanda-petanda.

\begin{tabular}{l|c|c|}
\cline { 2 - 3 } Language & 1. Signifier & 2. Signified \\
\cline { 2 - 3 } & 3. Sign & \\
\cline { 2 - 3 } MYTH & I. Signifier & II. Signified \\
\cline { 2 - 3 } & \multicolumn{2}{|c|}{ III. Signifier } \\
\hline
\end{tabular}

\section{c. Hipersemiotika dan Hiperealitas}

Piliang (2010: 51) menjelaskan bahwa hipersemiotika memiliki arti melampaui batas semiotika. Dunia hipersemiotika, dengan demikian tidak dapat dipisahkan dari dunia hiperealitas yang dilukiskan oleh Baudrilard-sebuah dunia realitas yang dalam konstruksinya tidak dapat dilepaskan dari produksi dan permainan bebas tanda-tanda yang melampaui (hyper-sign), sebuah tanda yang melampaui prinsip, definisi, struktur, dan fungsinya sendiri. Dunia hiperealitas, dengan demikian, dapat dipandang sebagai dunia perekayasaan (dalam pengertian distorsi) realitas lewat hyper-signs, sedemikian rupa, sehingga tanda-tanda tersebut kehilangan kontak dengan realitas yang direpresentasikannya. Hiperealitas menciptakan satu kondisi, yang di dalamnya kepalsuan berbaur dengan keaslian; masa lalu berbaur dengan masa kini; fakta bersimpang siur dengan rekayasa; tanda melebur dengan realitas; dusta bersenyawa dengan kebenaran. Kategori-kategori kebenaran, kepalsuan, keaslian, isu, realitas seakanakan tidak berlaku lagi di dalam dunia seperti itu (Piliang, 2010:53).

\section{d. Teori Komodifikasi}

Mosco (2010:129-133) menjelaskan bahwa komodifikasi merupakan proses transformasi nilai guna (use value) menjadi nilai tukar (exchange value). Sebuah barang dinilai tidak lagi berdasarkan kemampuannya memenuhi kebutuhan seseorang melainkan dinilai dengan apa yang dapat dibawanya di ranah pasar. Dalam kajian komunikasi Mosco, komodfikasi merupakan sebuah proses yang melibatkan perubahan atau transformasi pesan media menjadi produk yang dapat dipasarkan. Di samping itu, komunikasi menjadi dagangan yang paling digemari di era kapitalisme ini sebab nilai surplus yang dimiliki produk-produk komunikasi. Produk komunikasi terdiri dari simbol-simbol yang dapat membentuk kesadaran. Kesadaran inilah yang dimanfaatkan kapitalis untuk melanggengkan kekuasaannya.

\section{e. Maskulinitas}

Maskulinitas adalah imaji kejantanan, ketangkasan, keperkasaan/ keberanian untuk menantang bahaya, keuletan, keteguhan hati, hingga keringat yang menetes, otot laki-laki yang menyembul atau bagian tubuh tertentu dari kekuatan daya tarik laki-laki yang terlihat secara ekstrinsik (Jewitt, 2013).

Sifat-sifat maskulinitas yang dikemukakan oleh Deborah David and Robert Brannon adalah sebagai berikut (Levine, 1998:145).

1. No Sissy Stuff. Seorang laki-laki sejati harus menghindari perilaku atau karakteristik yang berasosiasi dengan perempuan.

2. Be a Big Wheel. Maskulinitas dapat diukur dari kesuksesan, kekuasaan, dan pengaguman dari orang lain. Seseorang harus mempunyai kekayaan, ketenaran, dan status yang sangat lelaki.

3. Be a Sturdy Oak. kelelakian membutuhkan rasionalitas, kekuatan, dan kemandirian. Seorang laki-laki harus tetap bertindak kalem dalam berbagai situasi, tidak menunjukkan emosi, dan tidak menunjukkan kelemahannya. 
4. Give em Hell: Laki-laki harus mempunyai aura keberanian dan agresi, serta harus mampu mengambil risiko walaupun alasan dan rasa takut menginginkan sebaliknya.

\section{DESKRIPSI OBJEK MATERIAL}

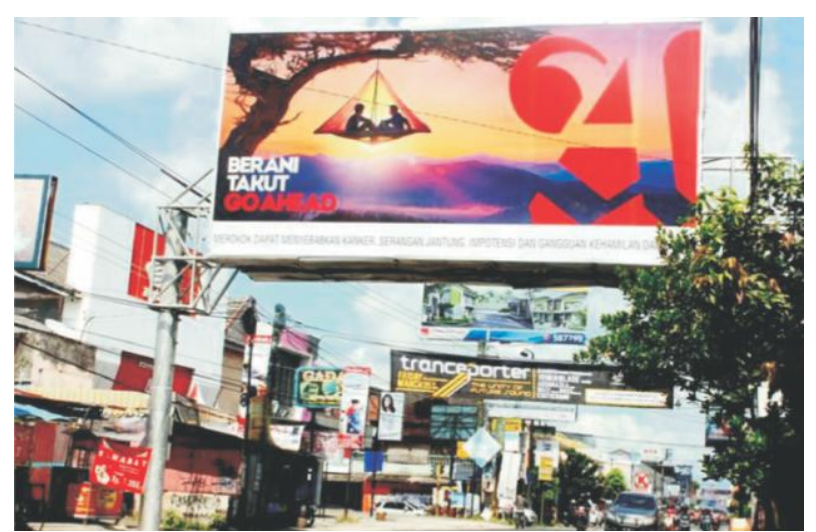

Advertiser : PT Hanjaya Mandala Sampoerna Tbk(HMSP)

Varian Produk : AMild

$\begin{array}{ll}\text { Versi } & : \text { Berani Takut } \\ \text { Media } & \text { :Outdoor }\end{array}$

Jenis : Baliho

Lokasi : Jl Godean Yogyakarta

Periode :April 2013

Secara konseptual, iklan A Mild versi "Berani Takut" menonjolkan petualangan dua orang lelaki berkelana menyusuri pegunungan. Secara komposisi visual terdapat beberapa objek utama, yaitu siluet dua orang lelaki berada di dalam tenda yang tergantung di atas pohon. Seting yang digunakan pada iklan tersebut adalah pegunungan. Langit ditampilkan dengan warna lembayung, menggambarkan suasana sore hari. Secara komposisi warna, iklan pada baliho tersebut memadukan langit lembayung keemasan seolah matahari akan tenggelam dan bersembunyi di balik birunya jajaran pegunungan yang membentang.

Pesan yang ingin disampaikan adalah pilihan untuk bertindak Berani atau Takut. Tagline "Go Ahead" meneriakkan semboyan untuk tetap Go Ahead terhadap apapun pilihan kita.

\section{ANALISIS FORMAL}

Analisis semiotika iklan rokok A Mild versi Berani Takut

1. Proses Semiosis melalui Pendekatan Roland Barthes

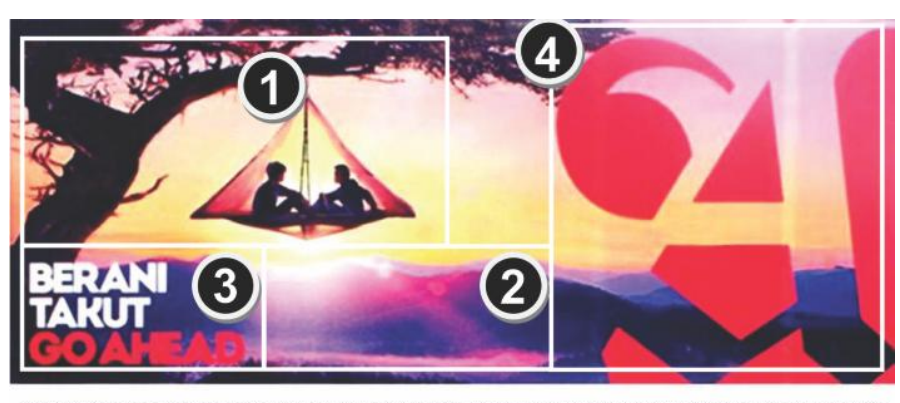

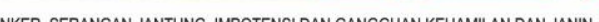

I. Language

Signifier

1. Siluet dua orang lelaki

2. Tenda yang tergantung di pohon

3. Pegunungan

4. Teks "Berani Takut Go Ahead"

5. Logo A Mild
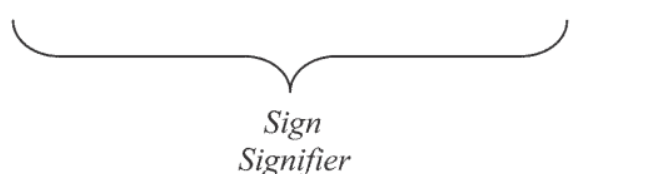

1. Siluet dua orang lelaki

2. Tenda yang tergantung di pohon

3. Pegunungan

4. Teks "Berani Takut Go Ahead"

'Keberanian dalam

'Petualangan'

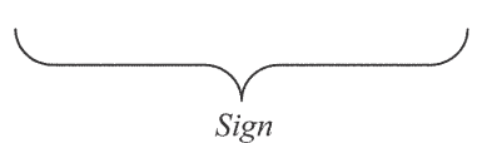

2. Analisis Visual

Pada tataran dennotative (denotasi), iklan rokok A Mild versi Berani Takut terdapat elemen-elemen penanda (signifier) dua orang lelaki yang sedang bercakap di dalam tenda yang tergantung pada batang pohon. Posisi pohon terletak diatas pegunungan yang sangat tinggi. Seting pegunungan menggambarkan mereka sedang melakukan perjalanan pendakian gunung. Warna langit lembayung menunjukkan suasana sore hari dan matahari akan segera tenggelam.

Bila dikaji lebih dalam pada tataran connotative meaning (konotasi), siluet dua orang lelaki di dalam tenda yang tergantung pada batang pohon tersebut menggambarkan imaji kejantanan terhadap petualangan yang mereka lakukan 
selama pendakian gunung. Siluet tersebut menggambarkan gesture yang tenang, nyaman, seolah tidak memiliki rasa takut terhadap resiko terjatuh dari ketinggian. Posisi kedua lelaki tersebut melambangkan keseimbangan, dan kerja sama yang solid. Keberhasilan pendakian gunung adalah jika telah mencapai puncaknya. Puncak diibaratkan sebagai tujuan atau target. Untuk mencapai sebuah tujuan yang besar dibutuhkan kerja sama yang solid serta keberanian dalam mengambil resiko. Keberanian dalam mengambil resiko yang besar merupakan tantangan yang hanya dimiliki oleh lelaki yang jantan.

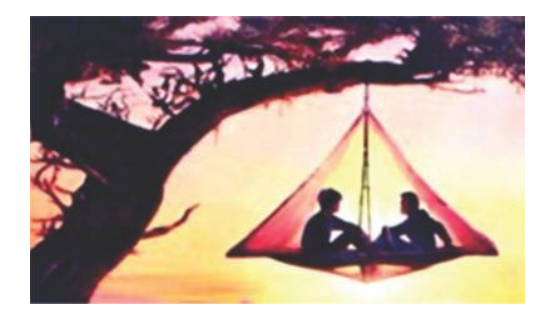

Warna langit lembayung menggambarkan suasana di sore hari. Dapat diartikan bahwa kedua lelaki ersebut membicarakan rencana perjalanan selanjutnya sambil menunggu malam tiba. Malam hari identik dengan suasana yang mencekam dan menakutkan, tetapi hal itu justru menjadikan tantangan bagi mereka yang berjiwa petualang. Seting pegunungan sekitar menggambarkan suasana sepi seolah area yang belum terjamah. Hal itu merepresentasikan kemandirian pada kedua lelaki tersebut.

\section{Analisis Verbal}

Pada tataran connotative meaning (konotasi), teks "Berani Takut Go Ahead", mengandung dua makna konotasi: (1) pilihan untuk berani atau takut; (2) berani terhadap keadaan yang menakutkan. Kata "Go Ahead" memberikan dorongan untuk tidak ragu-ragu dalam mengambil keputusan terhadap pilihanpilihan hidup. Ada prinsip peminjaman kode (the borrowing of code), yaitu kode pada bahasa teks yang memberi arti keberanian dan petualangan, serta penanda (signifier) dua orang lelaki yang sedang bercakap di dalam tenda yang tergantung pada batang pohon dengan seting pegunungan. Makna keberanian dan petualangan dipinjamkan pada rokok A Mild sebagai penanda.

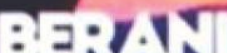 \\ तिग}

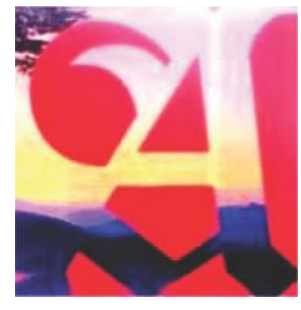

Logo A Mild tersebut merupakan representasi dari brand rokok A Mild. Apabila diartikan berdasarkan relasi elemen-elemen tanda pada iklan, maka rokok A Mild merupakan cerminan dari kejantanan pria yang memiliki keberanian dalam meghadapi resiko yang besar.

\section{INTERPRETASI}

Komodifikasi Maskulinitas

Berdasarkan hasil analisis semiotika dapat diinterpretasikan bahwa komoditas yang diangkat dalam iklan rokok A Mild versi "Berani Takut" memiliki relasi dengan sifat-sifat maskulinitas pria, seperti yang dikemukakan oleh Deborah David and Robert Brannon.

a. Kekuatan, kemandirian, bertindak kalem dalam berbagai situasi, tidak menunjukkan emosi, dan tidak memunjukkan kelemahannya memiliki relasi dengan sifat Be a Sturdy Oak.

b. Keberanian dan mampu mengambil risiko walaupun alasan dan rasa takut menginginkan sebaliknya memiliki relasi dengan sifat Give em Hell.

Terdapat transformasi nilai guna (use value) dari rokok menjadi penonjolan maskulinitas pria sebagai nilai tukar (exchange value) yang mengarah pada tujuan komersial. Kebiasaan merokok sama sekali tidak memiliki nilai guna menjadikan seorang perokok menjadi sosok yang kuat dan berani, melainkan berbagai penelitian menyatakan bahwa merokok dapat merugikan kesehatan.

Apabila ditinjau dari segi komodifikasi konten, iklan tersebut memiliki konten media yang dibuat sedemikian rupa agar benar-benar menjadi kesukaan publik meski hal itu bukanlah realitas dan kebutuhan publik. Pengesahan segala cara dilakukan demi mendapat perhatian audien yang tinggi sesuai dengan segmentasi pasar rokok A Mild, yaitu remaja kalangan menengah ke atas.

\section{Antara Maskulinitas dan Realitas}

Iklan tersebut menjadikan maskulinitas sebagai komodifikasi dalam penyampaian pesan iklan. Iklan A Mild versi "Berani Takut" menggunakan konsep maskulinitas yang berhubungan dengan keberanian dalam mengambil resiko (Be a Sturdy Oak), serta kekuatan, kemandirian, bertindak kalem dalam berbagai situasi (Give em Hell). 
1. Berdasarkan komposisi visual, iklan tersebut mengandung ideologi yang mengarah pada kejantanan pria (maskulinitas), akan tetapi menurut penelitian, kebiasaan merokok justru merugikan bagi kesehatan. Roan (1979: 33) mengatakan bahwa efek dari rokok atau tembakau dapat menimbulkan berbagai penyakit, sebagai berikut.

a. Penyakit paru

Merokok dapat menyebabkan perubahan struktur dan fungsi saluran napas dan jaringan paru-paru. Pada saluran napas besar, sel mukosa membesar dan kelenjar mukus bertambah banyak (hiperplasia). Pada saluran napas kecil, terjadi radang ringan hingga penyempitan akibat bertambahnya sel dan penumpukan lendir. Pada jaringan paru-paru, terjadi peningkatan jumlah sel radang dan kerusakan alveoli (cabang dari paru).

b. Penyakit jantung koroner

Nikotin dapat mengganggu irama jantung dan menyebabkan sumbatan pada pembuluh darah jantung, sedangkan $\mathrm{CO}$ menyebabkan pasokan oksigen untuk jantung berkurang karena berikatan dengan $\mathrm{Hb}$ darah.

c. Impotensi

Tjokronegoro, seorang dokter spesialis Andrologi Universitas Indonesia mengungkapkan bahwa nikotin yang beredar melalui darah akan dibawa keseluruh tubuh termasuk organ reproduksi. Zat ini akan menggangu proses spermatogenesis sehingga kualitas sperma menjadi buruk Sedangkan Taher menambahkan, selain merusak kualitas sperma, rokok juga menjadi faktor resiko gangguan fungsi seksual terutama gangguan disfungsi ereksi (DE).

d. Kanker kulit, mulut, bibir dan kerongkongan

Tar yang terkandung dalam rokok dapat mengikis selaput lender dimulut, bibir dan kerongkongan. Ampas tar yang tertimbun merubah sifat sel-sel normal menjadi sel ganas yang menyebakan kanker. Selain itu, kanker mulut dan bibir ini juga dapat disebabkan karena panas dari asap. Sedangkan untuk kanker kerongkongan, didapatkan data bahwa pada perokok kemungkinan terjadinya kanker kerongkongan dan usus adalah 5-10 kali lebih banyak daripada bukan perokok.

e. Merusak otak dan indera

Sama halnya dengan jantung, dampak rokok terhadap otak juga disebabkan karena penyempitan pembuluh darah otak yang diakibatkan karena efek nikotin terhadap pembuluh darah dan suplai oksigen yang menurun terhadap organ termasuk otak dan organ tubuh lainnya. Sehingga nikotin ini dapat mengganggu seluruh sistem tubuh.

\section{f. Mengancam kehamilan}

Hal ini terutama ditujukan pada wanita perokok. Banyak hasil penelitian yang menggungkapkan bahwa wanita hamil yang merokok meiliki resiko melahirkan bayi dengan berat badan yang rendah, kecacatan, keguguran bahkan bayi meninggal saat dilahirkan.

Penelitian terbaru juga menunjukkan adanya bahaya dari secondhandsmoke, yaitu asap rokok yang terhirup oleh orang-orang bukan perokok karena berada di sekitar perokok, atau biasa disebut juga dengan perokok pasif. Abdillah Ahsan, peneliti Lembaga Demografi FEUI, menuturkan, "Jelas sekali ada indikasi meningkatnya persentase orang merokok. Bahkan, persentase laki-laki merokok di Indonesia adalah yang tertinggi di dunia, yakni 67,4 persen”. Kecenderungan ini tentu merupakan sinyal bahaya, siaga satu kesehatan nasional. Terkait dengan struktur produktif yang saat ini mendominasi struktur penduduk Indonesia, konsumsi rokok yang meningkat juga meroketkan dampak negatif. Dampak buruk itu antara lain alokasi uang yang dihabiskan untuk membeli rokok dan mengorbankan pengeluaran lainnya yang lebih penting, seperti untuk gizi dan pendidikan, meningkatnya risiko terkena penyakit yang akan mengurangi produktivitas kerja, meningkatkan biaya kesehatan, dan meningkatkan risiko mati muda (www.bisniskeuangan.kompas.com, online).

\section{EVALUASI}

Apabila ditinjau dari segi kreativitas ide, iklan tersebut tidak jauh berbeda dari iklan-iklan rokok merek lain yang juga bertemakan petualangan pria. Namun, yang menjadikan iklan ini menarik adalah visualisasi dua orang lelaki yang ditampilkan dalam bentuk siluet sedang berada di dalam tenda yang tergantung pada pohon. Talent (model iklan) melakukan aktivitas layaknya seorang pendaki gunung. Akan terlihat kurang menantang ketika talent hanya ditampilkan berdiri atau duduk tanpa melakukan aktivitas yang membutuhkan nyali besar.

Selain itu, kekuatan iklan ini terletak pada pada permainan bahasa copywriting dan tagline yang sudah melekat di benak audience. Go Ahead, tagline yang singkat dan mudah diingat. Sesuai dengan gaya bahasa remaja kalangan menengah ke atas. Tagline dalam Bahasa Inggris mampu mendongkrak citra dan popularitas merek rokok A Mild. Kata berani takut mengandung penafsiran yang berbeda-beda bagi audience, tetapi visualisasi iklan ini mampu memperjelas penyampaian pesan ke audience dan membuat iklan ini komunikatif.

Permasalahan tentang iklan tidak hanya sekedar tinjauan kreatifitas dan estetikanya saja. Perlunya tinjauan terhadap moralitas sebagaimana moralitas menekankan baik atau buruk, kejujuran atau kebohongan, serta benar atau salah. Keterkaitan antara hasil analisis semiotika dengan dampak negatif dari kebiasaan 
merokok menjadikan iklan tersebut tidak menampilkan realitas produk yang sesungguhnya (mirror of reality), melainkan realitas yang tidak sesungguhnya dari sebuah produk (distorted of mirror reality). Maskulinitas merupakan refleksi dari sebuah realitas yang palsu (false) atau menyesatkan (deceptive). Tanda telah melebur dengan realitas; dan dusta pun bersahabat dengan kebenaran. Kategorikategori kebenaran, kepalsuan, keaslian, isu, realitas seakan-akan tidak berlaku lagi di dalamnya.

Iklan rokok tersebut merupakan konstruksi hiperealitas seperti yang dilukiskan oleh Baudrilard-sebuah dunia realitas yang dalam konstruksinya tidak bisa dilepaskan dari produksi dan permainan bebas tanda-tanda yang melampaui (hyper-sign)-sebuah tanda yang melampaui prinsip, definisi, struktur, dan fungsinya sendiri. Produksi tanda-tanda yang dilahirkan oleh iklan membentuk konstruksi dunia perekayasaan (dalam pengertian distorsi) realitas lewat hypersigns, sedemikian rupa, sehingga tanda-tanda tersebut kehilangan kontak dengan realitas yang direpresentasikannya.

Iklan rokok A Mild versi "Berani Takut" merupakan salah satu contoh iklan komersial atau dengan kata lain diciptakan untuk kepentingan kapitalis yang dikemas secara halus menawarkan citra maskulinitas namun dibalik topengnya tersimpan realita yang menyesatkan.

\section{KESIMPULAN}

Berdasarkan serangkaian hasil analisis, maka diperoleh kesimpulan sebagai berikut: pertama, iklan rokok A Mild versi Berani Takut menjadikan maskulinitas sebagai bentuk komodifikasi dalam penyampaian pesan iklan Komoditas yang diangkat dalam iklan rokok A Mild versi Berani Takut memiliki relasi dengan sifat-sifat maskulinitas pria seperti yang dikemukakan oleh Deborah David and Robert Brannon. Kekuatan, kemandirian, bertindak kalem dalam berbagai situasi, tidak menunjukkan emosi, dan tidak menunjukkan kelemahannya memiliki relasi dengan sifat Be a Sturdy Oak. Keberanian dan mampu mengambi risiko walaupun alasan dan rasa takut menginginkan sebaliknya memiliki relasi dengan sifat Give em Hell.

Kedua, hubungan antara komodifikasi maskulinitas dan realitas adalah bertolak belakang. Imaji maskulinitas yang dibentuk dari iklan hanyalah fragmen ideologi yang terbentuk dari konotator pada tahapan mitos. Merokok seringkali dikaitkan dengan keberanian dan segala hal yang terkait dengan kejantanan lelaki, namun faktanya merokok justru merugikan kesehatan bagi diri sendiri dan orang lain sekitar yang ikut menghirupnya. Hubungan antara komodifikasi maskulinitas dan realitas akan disajikan dalam skema berikut:

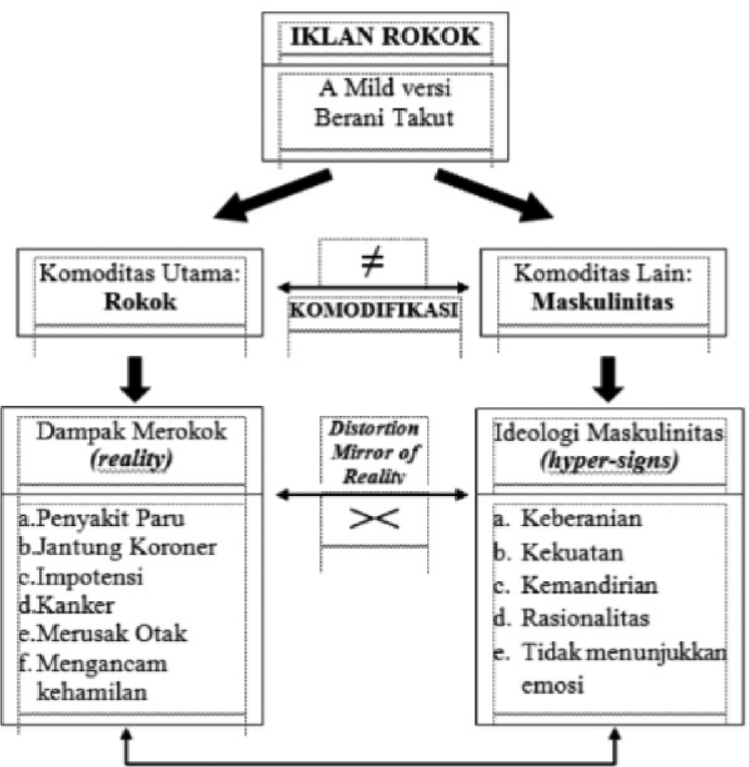

Skema 1. Hubungan Antara Komodifikasi Maskulinitas dan Realitas Pada Iklan Rokok

Ketiga, keterkaitan antara hasil analisis semiotika dengan ketiga contoh iklan tersebut tidak menampilkan realitas produk yang sesungguhnya (mirror of reality), melainkan realitas yang tidak sesuangguhnya dari sebuah produk (distorted of mirror reality). Maskulinitas merupakan refleksi dari sebuah realitas yang palsu (false) atau menyesatkan (deceptive).

\section{DAFTAR PUSTAKA}

Barthes, Roland. 1981. Elements of Semiology. New York: Hill and Wang. 1983. Mythologies. London: Granada.

Levine, Martin P. 1998. Gay Macho. New York: New York University Press.

Mosco, Vincent. 2010. The Political Economy of Communication 2 Edition. London: Sage Publicaion.

Piliang, Yasraf Amir. 2010. Hipersemiotika Tafsir Cultural Studies Atas Matinya Makna. Yogyakarta: Jalasutra.

Roan. 1979. Ilmu Kedokteran Jiwa. Jakarta: PT Rajawali Press. Internet

http://www.sampoerna.com/id_id/our_products/pages/our_brands.aspx. Diunduh 8 Mei 2013

Jewitt, Carey. Images of Men: Male Sexuality in Sexual Health Leaflets and Posters for Young People. 
54 imaji, Vol. 12, No. 2, Agustus $2014: 39$ - 54

Diakses di http://socresonline.org.uk/2/2/6.html, 10 April 2013.

Peraturan Pemerintah Republik Indonesia Nomor 109 Tahun 2012 Tentang Pengamanan Bahan Yang Mengandung Zat Adiktif Berupa Produk Tembakau Bagi Kesehatan. 2012. Diunduh 7 April 2013 dari http://www.depkes.go.id/downloads/PP/PP\%20tahun\%202012\%20tenta ng\%2020PENGAMANAN\%20BAHAN\%20YANG\%20MENGANDU NG\%20ZAT\%20ADIKTIF\%20BERUPA\%20PRODUK\%20TEMBAK AU\%20BAGI\%20KESEHATAN.pdf.

Sanjoyo, Anton. 2013. TakAda Lagi Perdebatan Soal Ekonomi Rokok. Diunduh 22 Maret 2013 dari http://bisniskeuangan.kompas.com/read/2013/02/01/ 02591685.

Suwismo, Andryanto, \& Wijaya, Dhani. 2012. Valuasi HM Sampoerna Tertinggi di Sektor Rokok. Diunduh 6 Mei 2013 dari http://agro.kemenperin.go.id/ 646-Valuasi-HM-Sampoerna-Tertinggi-di-Sektor-Rokok. 